\title{
Maintenance Guide for Florida Microirrigation Systems ${ }^{1}$
}

Thomas Obreza ${ }^{2}$

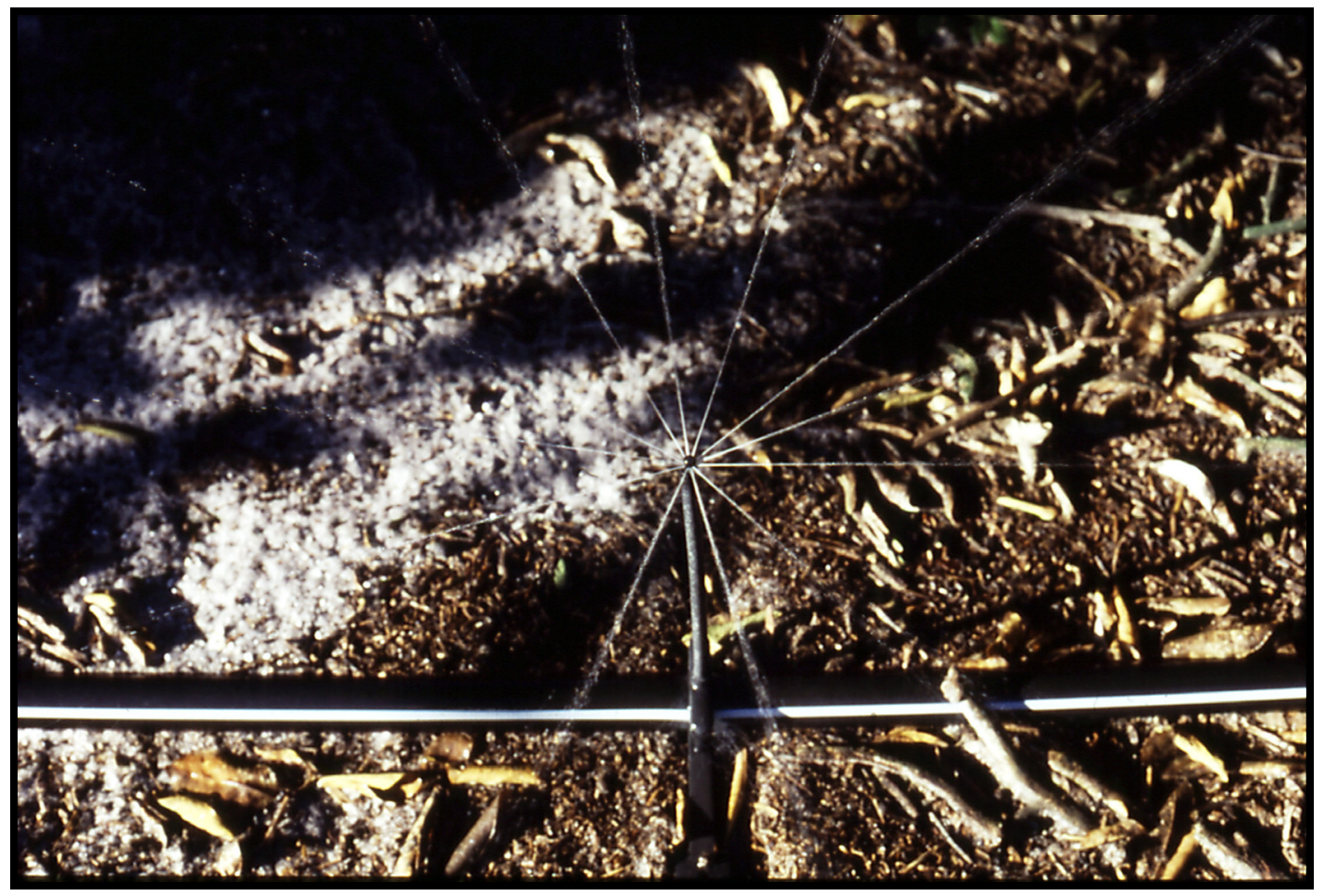

1. This document is CIR 1449, a circular of the Soil and Water Science Department, Florida Cooperative Extension Service, Institute of Food and Agricultural Sciences, University of Florida. Original publication date: April 2004. Visit the EDIS Web Site at http://edis.ifas.ufl.edu.

2. Thomas Obreza, Professor, Soil and Water Science Department, Florida Cooperative Extension Service, Institute of Food and Agricultural Sciences, University of Florida, Gainesville, 32611-0290.

The Institute of Food and Agricultural Sciences is an equal opportunity/affirmative action employer authorized to provide research, educational information and other services only to individuals and institutions that function without regard to race, color, sex, age, handicap, or national origin. For information on obtaining other extension publications, contact your county Cooperative Extension Service office. Florida Cooperative Extension Service, Institute of Food and Agricultural Sciences, University of Florida. Larry R. Arrington, Interim Dean. 


\section{MAINTENANCE GUIDE FOR FLORIDA MICROIRRIGATION SYSTEMS \\ Table of Contents}

1. Introduction

2. Evaluating the irrigation system: Using your local Mobile Irrigation Laboratory

3. Testing the irrigation water source

4. Routine maintenance of system components

4.1. Pumps

4.2. Power units

4.3. Water filters

4.4. Chemical injection equipment

4.5. Automatic valves

4.6. Pressure gauges and flow meters

4.7. Field pipe, tubing, and emitters

4.8. Line flushing

5. Water treatment to prevent emitter plugging

5.1. Biocides

5.1.1. Chlorine

5.1.2. Copper sulfate

5.1.3. Chelated copper

5.2. Acidification

5.3. Synthetic scale inhibitors

5.3.1. General information

5.3.2. Polyphosphates

5.3.3. Phosphonates and polyelectrolytes

5.4. Evaluating water conditioning treatments

5.4.1. Monitor the system to detect plugging

5.4.2. Use scale-monitoring devices to evaluate cleaning

6. Remedial maintenance for microirrigation systems affected by scaling or plugging

6.1. Emitter maintenance and reclamation

6.2. Purging with acid

6.3. Other purge chemicals

6.4. Evaluating system purge treatments

6.4.1. Evaluation using tubing inserts

6.4.2. Water application uniformity evaluation

7. Additional information about iron, manganese, and sulfide

7.1. Iron and manganese

7.2. Sulfides 


\section{Summary}

9. References and further reading

Appendix 1: General summary of microirrigation problems and possible solutions

Appendix 2: Acidifying irrigation water to prevent calcium carbonate scale formation.....When and how to do it

\section{ACKNOWLEDGEMENTS}

Compilation and publication of this guide was supported in part by funds from the Southwest Florida Water Management District. A portion of the information contained herein was adapted from material produced by Dr. Donald Pitts, formerly Assistant Professor of Agricultural Engineering, University of Florida. Assistance provided by Esa Ontermaa, Zoe Shobert, and Benno Eidus is also greatly appreciated. 


\section{MAINTENANCE GUIDE FOR FLORIDA MICROIRRIGATION SYSTEMS}

\section{INTRODUCTION}

Florida's microirrigation systems are technically more complex than sprinkler or flood irrigation systems. They require significant maintenance to assure maximum operational efficiency. The intent of this guide is to help Florida microirrigation system managers and operators keep their systems running at top efficiency, which will improve crop production and conserve Florida's water resources.

- The performance of a microirrigation system may rapidly deteriorate if it is not routinely maintained by:

○ Checking for leaks.

○ Backwashing and cleaning filters.

- Periodic line flushing.

- Using a biocide like chlorine.

- Acidifying (if necessary).

- Cleaning or replacing plugged emitters.

○ Evaluating and monitoring system performance.

- Proper maintenance of a microirrigation system will:

○ Extend system life.

- Improve performance.

- Minimize shut-down time.

- Reduce the probability of non-uniform water and fertilizer applications due to emitter plugging.

- Reduce operating costs.

- Save water and fertilizer.

- Improve production.

- Provide maximum benefits for freeze protection.

\section{EVALUATING THE IRRIGATION SYSTEM: USING YOUR LOCAL MOBILE} IRRIGATION LABORATORY

- Mobile Irrigation Labs (MILs) are typically associated with USDA-NRCS field offices or local Soil and Water Conservation Districts. They consist of:

- One or two people.

- A vehicle.

○ Specialized equipment used to evaluate irrigation systems. 
- MILs provide irrigation system evaluation and educational information to help conserve water resources:

- They identify irrigation system problems and provide recommendations to correct them.

- They guide selection and installation of new systems.

- They assist with irrigation management planning.

- Some MILs provide irrigation management tools.

- The goal of the MIL is to educate irrigation system operators on the efficient use of irrigation water.

- Immediate benefits are reduced pumping costs and fertilizer requirements.

- Longer term benefits include reduced offsite water quality impacts, improved water and soil conservation, and improved crop production.

- Contact your local NRCS field office, Soil and Water Conservation District, or Water Management District to find a MIL operating in your area.

\section{TESTING THE IRRIGATION WATER SOURCE}

- Before implementing routine or remedial maintenance on a Florida microirrigation system, test the water source for physical, chemical, and biological properties to determine emitter plugging potential.

- It is important to take a representative water sample:

- If the water source is a well, collect the sample after the pump has run for about half an hour.

- If sampling surface water, collect the sample near the center of the source about $1 \mathrm{ft}$ below the water surface.

- Check for water source variability by taking samples several times during the irrigation season.

- To accurately measure water $\mathrm{pH}$, alkalinity, dissolved iron, and hydrogen sulfide, analyze well water with a field test kit immediately after sampling.

- Use Table 1 to estimate the plugging hazard of irrigation water based on a standard analysis. 
Table 1. Chemical criteria for plugging potential of microirrigation water sources (Pitts, 1990).

\begin{tabular}{|c|c|c|c|}
\hline \multirow[t]{2}{*}{ Factor } & \multicolumn{3}{|c|}{ Plugging hazard based on concentration } \\
\hline & Slight & Moderate & Severe \\
\hline Suspended solids ${ }^{1}$ & $<50$ & 50 to 100 & $>100$ \\
\hline $\mathrm{pH}$ & $<7.0$ & 7.0 to 7.5 & $>7.5$ \\
\hline Total dissolved solids ${ }^{1}$ & $<500$ & 500 to 2000 & $>2000$ \\
\hline Iron $^{1}$ & $<0.1$ & 0.1 to 1.5 & $>1.5$ \\
\hline Manganese $^{1}$ & $<0.1$ & 0.1 to 1.5 & $>1.5$ \\
\hline Calcium ${ }^{1}$ & $<40$ & 40 to 80 & $>80$ \\
\hline Alkalinity as $\mathrm{CaCO}_{3}{ }^{1}$ & $<150$ & 150 to 300 & $>300$ \\
\hline Hydrogen sulfide $^{1}$ & $<0.2$ & 0.2 to 2.0 & $>2.0$ \\
\hline Bacteria $(\# / m L)$ & $<10,000$ & 10,000 to 50,000 & $>50,000$ \\
\hline
\end{tabular}

${ }^{1}$ Concentration as milligrams per liter $(\mathrm{mg} / \mathrm{L})$ or parts per million $(\mathrm{ppm})$.

\section{ROUTINE MAINTENANCE OF SYSTEM COMPONENTS}

Routine maintenance involves "preventative" practices that all Florida microirrigation systems should receive regardless of age. Proper attention to the following will decrease the likelihood of irrigation system failure.

\subsection{Pumps}

- Follow manufacturer's recommendations to maintain submersed turbine or above-ground centrifugal pumps.

- Turbine pumps require little maintenance. If failure does occur, repair requires the removal of the pump, which can be complicated and expensive.

- During the irrigation season, check above-ground pumps at each site visit for:

- Excessive or unusual noise or vibration.

- Water leakage.

- Proper flow rate and pressure.

- Intake screen obstructions.

\subsection{Power units}

- In Florida, most pumps are powered by diesel engines. During the irrigation season, visually check the engine at each site visit for:

- Proper oil pressure and coolant temperature.

- Fluid (oil, fuel, coolant) leaks or stains.

- Excessive noise or vibration.

- Regularly check the engine oil level with the system off. 
- Change the following based on the manufacturer's recommendation:

$\circ$ Engine oil.

- Engine coolant.

○ Oil and fuel filters.

- Tune up the engine and take other preventative measures once a year or as the manufacturer recommends.

\subsection{Water filters}

Proper water filter performance is critical to minimize emitter plugging. Filters must be periodically cleaned of accumulated particles and debris. Backwashing is a typical cleaning method. A partially clogged filter may reduce system pressure, resulting in reduced and non-uniform water application. Clogged filters also increase pump pressure head and consume extra energy.

- Schedule filter backwashing either manually based on a time interval or automatically based on pressure differential.

- If possible, use automatic backwashing. Set the automatic backwash to operate on a 5 to 6 psi pressure differential.

- If backwashing manually, determine cleaning frequency based on the length of time it takes for particles to accumulate.

- During irrigation periods, inspect screen and disk filters monthly (or more frequently if needed) by removing the cover and examining the filter element:

- With screen filters, check for tears or extruded material in the screen.

- With disk filters, check for accumulated organic material on the outside of the disks, and check for sand or other particles that may have become wedged between disks.

- Check sand media filters at least twice a year:

- Check for appropriate sand level.

- Look for caked material in the media.

- Make sure media has not flushed out during backwash.

- Make sure cavities have not opened up.

- Routinely inspect all components related to automatic backwashing:

- Hydraulic tubing.

- Pressure regulators.

- Pressure gauges.

- Control valves. 


\subsection{Chemical injection equipment}

- Visually inspect injection equipment components each time a chemical is injected into the irrigation system:

○ Hoses.

○ Valves.

○ Pumps.

○ Injector.

- Be sure to flush the injection system with water following each chemical injection so corrosive chemicals do not remain in the equipment.

\subsection{Automatic valves}

Automatic diaphragm valves are relatively reliable but require periodic inspection to assure proper operation. If a valve failure goes undetected, the pump or power unit could be damaged or water could be applied where it is not needed.

- Inspect and clean diaphragm valves at least once a year. A valve can usually be cleaned without removing it from the line.

- Clean deposits that have accumulated on the valve stem.

- Remove encrustation with a wire brush, a weak acid (like vinegar), or very fine sand paper.

- When a valve is opened, inspect the diaphragm, seat, and o-ring seals. Replace any components that are beginning to wear out.

- Periodically inspect adjustable pressure regulating valves to ensure correct setting.

- If regulating valves are pre-set, check them with a pressure gauge mounted at the regulator, or by attaching a portable pressure gauge to a Schrader valve.

\subsection{Pressure gauges and flow meters}

- Check pressure gauges occasionally to make sure they are working.

○ Use high-quality liquid-filled gauges.

- Make sure the range of pressure measured by the gauge covers the operating range of the system.

- Check gauge accuracy by comparing with a new gauge or a standard test gauge.

- Occasionally observe flow meters while the irrigation system is operating.

- Make sure the flow rate observed is reasonable for the system.

- Repair or replace a malfunctioning flow meter as soon as possible. 


\subsection{Field pipe, tubing, and emitters}

Visually check irrigation system field components for leaks each time you visit a running system. Leaks can develop in plastic system parts (often resulting from animal chewing) and in hardware components like pipe fittings, emitters, and hose adapters.

- Walk or ride the field, observing or listening for excessive water flow.

- When micro sprinkler stakes are knocked over, the wetted pattern becomes grossly distorted. Check for this problem by surveying running emitters.

\subsection{Line flushing}

Particulate matter not removed by filters accumulates in irrigation pipes and laterals. Chemical precipitation may occur inside pipelines after the irrigation system shuts down. Suspended materials will be carried with the irrigation water, but as the water velocity decreases near the end of lines, particles will settle. If these sediments are allowed to build up, they will eventually plug emitters.

- Periodically flush the entire irrigation pipe system (mainlines, sub-mains, headers, manifolds and lateral lines).

- Manually flush lateral lines by opening only a few at a time. The desired flushing water velocity to remove larger and denser particles is 1 to $2 \mathrm{ft} / \mathrm{sec}$.

- Determine flushing velocity by measuring the volume of water flowing from an open lateral for 1 minute. Use Table 2 to determine if minimum flushing velocities are achieved.

Table 2. Pipe diameter vs. minimum water flow (gal/min) needed to achieve an effective flushing velocity.

\begin{tabular}{|cc|}
\hline $\begin{array}{c}\text { Pipe or tubing size } \\
\text { (inches) }\end{array}$ & $\begin{array}{c}\text { Flow required for } \mathbf{1} \mathbf{f t} / \mathbf{s e c} \\
\text { (gal//min) }\end{array}$ \\
\hline $1 / 2$ & 1.0 \\
$3 / 4$ & 1.7 \\
1 & 2.7 \\
$11 / 4$ & 4.7 \\
$11 / 2$ & 6.3 \\
2 & 12.0 \\
3 & 26.0 \\
4 & 42.0 \\
\hline
\end{tabular}

- Examine the flushed material to get an idea of potential plugging problems (Fig. 1). Hold a plastic sheet, nylon sock, or jar at the end of the lateral line to catch the first bit of debris as it leaves the pipe. 


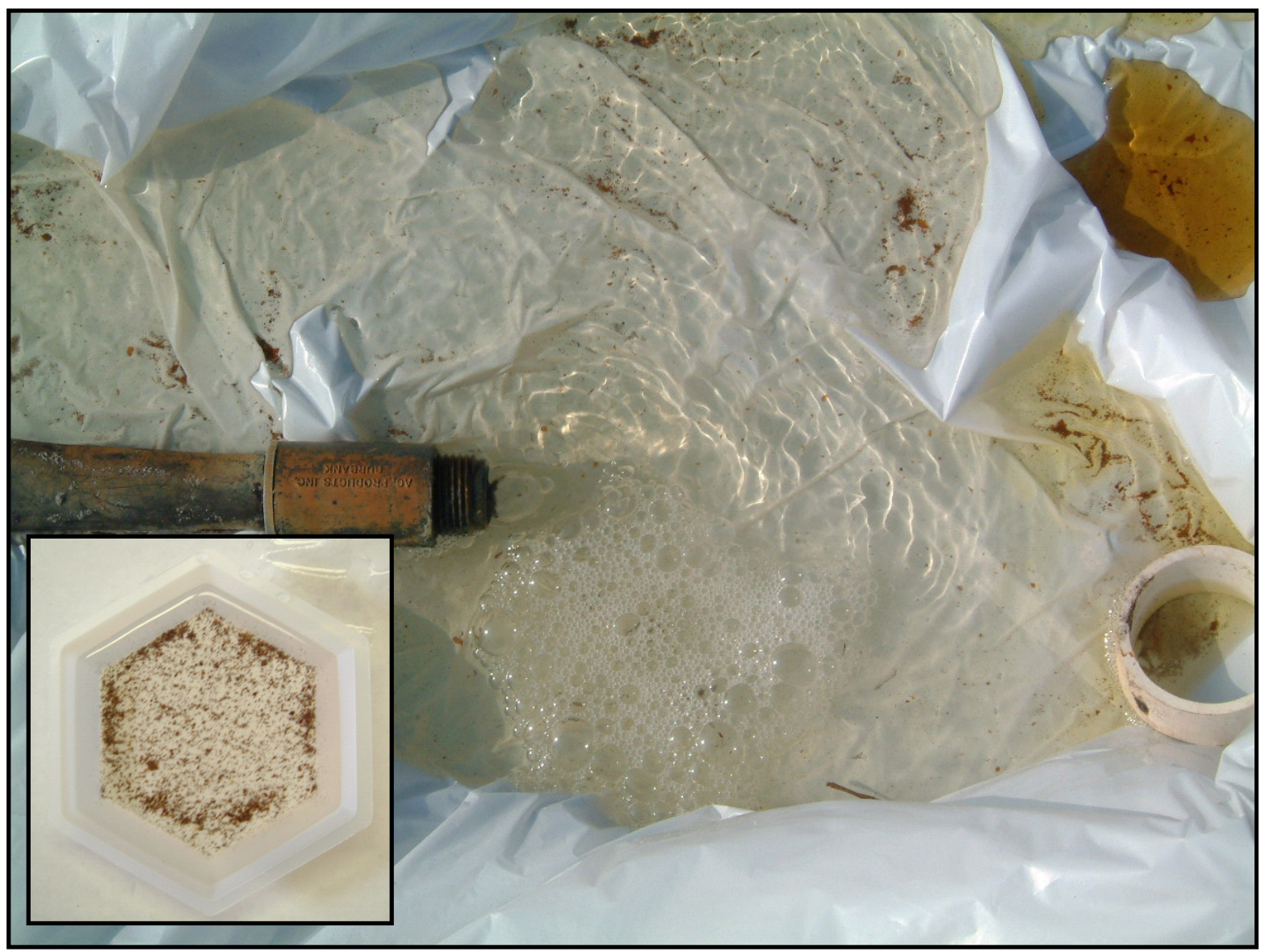

Fig. 1. Catching material flushed from lateral tubing helps estimate the amount of scale in the tube and its composition. In this case, the flushed material appears to be iron-based scale (inset).

- Determine future flushing frequency based on the amount of material that flushes out:

- Increase the flushing interval if only a small amount of suspended particles are flushed from the pipe.

○ Reduce the flushing interval if large amounts of material are flushed.

- After fertilizer is injected, run the system long enough to wash it out of the irrigation system. If chlorine is injected, this extra run time is not necessary.

- Occasionally irrigation pipes must be cut for maintenance or repairs. Prevent plastic cuttings or shavings from plugging emitters:

- Use tube cutters rather than saws for repairs.

- If a saw must be used, clean and flush the repaired section before reconnecting it to the irrigation system. 


\section{WATER TREATMENT TO PREVENT EMITTER PLUGGING}

- Preventing emitter plugging is best accomplished by continuous or intermittent water treatment with organic or inorganic chemicals that are able to:

○ prevent biological growths,

○ prevent precipitation reactions, or

- dissolve scale deposited on the inside surfaces of tubing and emitters.

- Preventative treatments greatly reduce the need for system flushing. Water treatment chemicals vary widely in stability, mode of action, corrosiveness, safety of use, dosage, and cost.

\subsection{Biocides}

\subsubsection{Chlorination}

Chlorination is the most widely used chemical irrigation water treatment to prevent biological emitter plugging. Chlorine injected into irrigation water kills microorganisms like algae and bacteria. These organisms are most commonly found in surface water, but they may also be present in ground water.

\section{Types and use of chlorine}

- Chlorine sources may be gas, liquid, or solid:

- Chlorine gas is the most effective and economical source, but there is some resistance to its use due to high toxicity.

- Sodium hypochlorite $(\mathrm{NaOCl})$ solution (household bleach) is readily available and is relatively safe to handle.

- Calcium hypochlorite $\left(\mathrm{Ca}(\mathrm{OCl})_{2}\right)$ is a powder or pellets (swimming pool chlorine) that must be dissolved in water to form a stock solution. Calcium hypochlorite may cause calcium precipitation in alkaline irrigation water, so it is not recommended for use in Florida.

- Use Table 3 to compare the available $\mathrm{Cl}$ provided by other $\mathrm{Cl}$ sources with chlorine gas. 
Table 3. Quantities of various chlorine compounds providing as much available chlorine as $1 \mathrm{lb}$ of chlorine gas.

\begin{tabular}{|lcc|}
\hline \multicolumn{1}{|c}{ Source } & $\begin{array}{c}\text { Available } \\
\text { chlorine }\end{array}$ & $\begin{array}{c}\text { No. of lbs equivalent } \\
\text { to 1 lb of chlorine gas }\end{array}$ \\
\hline Chlorine gas & 100 & 1.0 \\
Calcium hypochlorite (swimming pool chlorine) & 65 & 1.5 \\
Lithium hypochlorite & 36 & 2.8 \\
Sodium hypochlorite (laundry bleach) & 10 & 10.0 \\
Trichloroisocyanuric acid & 90 & 1.1 \\
Sodium dichloroisocyanurate & 63 & 1.6 \\
Potassium dichloroisocyanurate & 60 & 1.7 \\
Chlorine dioxide & 4 & 25.0 \\
\hline
\end{tabular}

- For economy, use chlorine gas to control bacterial slime deposits in microirrigation systems where continuous chlorination is needed.

- Gas chlorine is contained in steel cylinders and does not lose its strength in storage as liquid sodium hypochlorite does.

- Modern gas injectors only allow chlorine to be delivered under a vacuum. Gas is drawn from the tank by a venturi suction device driven by water flow.

- If the vacuum line breaks or if any part of the vacuum system is damaged, gas flow shuts off immediately.

- Inject chlorine continuously if the irrigation water contains high algae or bacteria concentrations:

- Inject chlorine at low concentration, resulting in at least $0.5 \mathrm{ppm}$ of "free" chlorine at the end of the farthest lateral line.

- No damage to plants will occur when irrigating with low chlorine water. Active chlorine is rapidly deactivated in the soil.

- Inject chlorine weekly or bi-weekly to achieve about 50 ppm "free" chlorine at the end of the farthest lateral line if the water source is low in algae or bacteria.

- Superchlorinate up to $500 \mathrm{ppm}$ to reclaim a system that has bacteriallyplugged emitters. WARNING: Super-chlorination may damage sensitive plants and irrigation system components.

- For most large microirrigation systems, it takes about 20 to 30 minutes for an injected chemical to travel to the farthest emitter. Determine travel time for specific systems by:

- Injecting soap and measuring the time it takes for bubbles to appear at the farthest emitter. 
- Injecting fertilizer and measuring the time it takes to observe an increase in electrical conductivity of the water at the end of the system.

- Use a field test kit to measure chlorine concentration in irrigation lines:

- Analyze for free chlorine; measuring total chlorine is not as meaningful.

- Natural water has an inherent chlorine demand; use trial and error to achieve a specific free residual chlorine concentration.

- Chlorine reacts with suspended organic matter, soil particles, and other dissolved constituents.

- Hydrogen sulfide consumes about 2 ppm chlorine for each ppm of sulfide, while iron consumes about 0.7 ppm chlorine for each ppm of iron.

\section{Effects of chlorine}

- Chlorine has different effects, depending on concentration:

- At low concentration ( 1 to 50 ppm), it kills microbes and oxidizes iron.

- At higher concentration (100 to 500 ppm) it can oxidize organic matter, and can be used to disintegrate organic materials that have accumulated in emitters.

- Always contact the manufacturer of your irrigation system components to verify emitter resistance to super-chlorination, since emitter parts may be made of silicon or other materials that chlorine will degrade.

- Chlorine behavior in water:

o When chlorine is injected into water, free chlorine is composed of hypochlorous acid $(\mathrm{HOCl})$ and hypochlorite $(\mathrm{OCl})$. The following reaction is for chlorine gas:

\begin{tabular}{|cc}
$\mathrm{Cl}_{2}$ \\
Chlorine
\end{tabular}$+\underset{\text { Water }}{\mathrm{H}_{2} \mathrm{O}} \rightarrow \underset{\text { Hypochlorous acid }}{\mathrm{HOCl}}+\underset{\text { Acid }}{\mathrm{H}^{+}}+\underset{\text { Chloride }}{\mathrm{Cl}^{-}}$

- The amount of $\mathrm{HOCl}$ that dissociates to $\mathrm{OCl}^{-}$depends on the $\mathrm{pH}$ of the water:

$\underset{\text { Hypochlorous acid }}{\mathrm{HOCl}} \leftrightarrow \underset{\begin{array}{c}\mathrm{H}^{+} \\ \text {Acid }\end{array}}{\mathrm{H}^{+}}+\underset{\text { Hypochlorite }}{\mathrm{OCl}^{-}}$


- The lower the water $\mathrm{pH}$, the more the chlorine exists as $\mathrm{HOCl}$ (Fig. 2).

- $\mathrm{HOCl}$ is about 60 times more powerful as a biocide than OCl-. For a more economical chlorine treatment, acidify alkaline water so that hypochlorous acid $(\mathrm{HOCl})$ predominates.

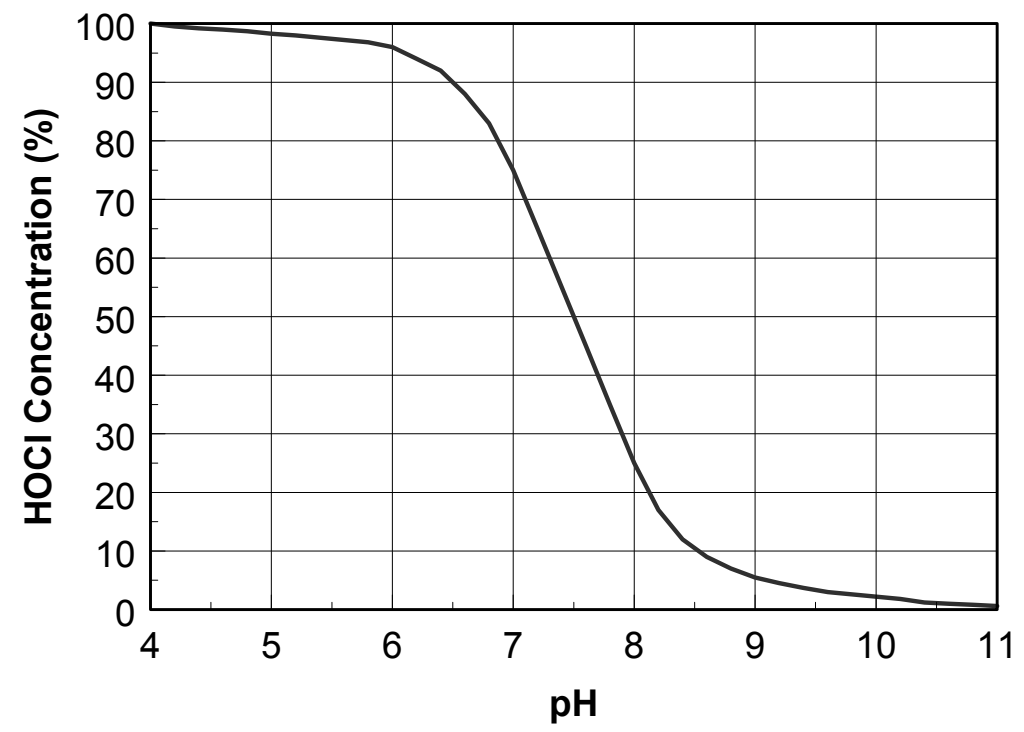

Fig. 2. Chlorine activity decreases as water pH increases.

\section{Chlorine injection example \#1}

At a pH of 7.5, a chlorine injection rate of $10 \mathrm{ppm}$ was required to maintain $1 \mathrm{ppm}$ free chlorine at the end of the last lateral. If the water is acidified to $\mathrm{pH} 6.5$, estimate the new liquid chlorine injection rate required to maintain the same free chloride concentration.

\section{Answer}

From Fig. 2, the $\mathrm{HOCl}$ concentration at $\mathrm{pH} 7.5$ is $45 \%$, and at $\mathrm{pH}$ $6.5 \mathrm{HOCl}=90 \%$.

Therefore, $0.45 \times 10 \mathrm{ppm}=0.90 \times \mathrm{M}$ $\mathrm{M}=5 \mathrm{ppm}$.

The required chlorine injection rate could be cut in half by lowering the water $\mathrm{pH}$ from 7.5 to 6.5 . 


\section{Injecting chlorine}

- Use this formula to establish the starting point for liquid sodium hypochlorite injection:

$$
\begin{aligned}
& I_{\text {liquid chlorine }}=(0.006 \times \mathrm{P} \times \mathrm{Q}) / \mathrm{m} \\
& \mathrm{I} \text { = gallons of liquid sodium hypochlorite injected per hour, } \\
& P=\text { parts per million desired, } \\
& Q=\text { system flow rate in gpm, } \\
& \mathrm{m}=\text { percentage chlorine in the source (usually } 5.25 \% \text { or } \\
& 10 \%) \text {. }
\end{aligned}
$$

\section{Chlorine injection example \#2}

Determine the liquid chlorine injection rate given these conditions: 1 ) the chlorine source is a $10 \%$ sodium hypochlorite solution, 2) the system flow rate is $1000 \mathrm{gpm}$, and 3) the desired concentration is $5 \mathrm{ppm}$.

\section{Answer}

$(0.006 \times 5 \mathrm{ppm} \times 1000 \mathrm{gal} / \mathrm{min}) / 10=3 \mathrm{gph}$

\section{Chlorine injection example \#3}

Determine the gas chlorine injection rate given these conditions: 1) the system flow rate is $1000 \mathrm{gpm}$, and 2) the desired concentration is $5 \mathrm{ppm}$.

\section{Answer}

$(0.012 \times 5 \mathrm{ppm} \times 1000 \mathrm{gal} / \mathrm{min})=60 \mathrm{lbs} /$ day

- Use this formula when injecting chlorine gas:

$$
\begin{aligned}
& I \text { gas chlorine }=(0.012 \times P \times Q) \\
& I=\text { chlorine gas injection rate }(\text { lbs/day }), \\
& P=\text { parts per million desired, } \\
& Q=\text { system flow rate in gpm. }
\end{aligned}
$$


- Take these precautions when injecting chlorine:

- If injecting acid and chlorine at the same time, do so at two different injection points. Mixing acid and liquid chlorine together will produce highly toxic chlorine gas. Never store acids and chlorine together.

- Do not inject herbicides and pesticides simultaneously with chlorine because the organic chemicals may break down.

- Always add chlorine to water, not vice versa.

o Inject chlorine upstream of the filter:

- Chlorine will help keep the filter clean.

- The filter will remove precipitates caused by chlorine injection.

- Liquid chlorine deteriorates with time.

- Shield storage tanks from the sun to reduce degradation.

- Use chlorine as soon as possible after receiving it.

\subsubsection{Copper sulfate}

- Copper sulfate is occasionally used to prevent bacterial growth in microirrigation systems due to the toxicity of copper.

- Chlorine is more effective, less expensive, and causes fewer plant toxicity and aluminum corrosion problems than copper sulfate. However, it is now included in some commercial irrigation line cleaning mixtures together with citric acid to reduce slimy bacterial growth.

- Copper sulfate is commonly used for pond treatment to suppress algae. Even at relatively high concentration (around $30 \mathrm{ppm}$ ), copper sulfate will not be completely effective because algal spores can exclude it.

\subsubsection{Chelated copper}

- Chelated copper acts as a bactericide similar to copper sulfate. Its advantage is that it is effective when injected at much lower rates (about 1 ppm).

- It is usually not necessary to inject copper compounds for an entire irrigation cycle. Copper can be injected during the latter part of the cycle, which leaves an effective residue in the lines to prevent bacterial growth after the system is shut down. 


\subsection{Acidification}

- Add acid to irrigation water to help prevent emitter plugging:

- Lowering the water $\mathrm{pH}$ can enhance the effectiveness of chlorine.

- The pH-lowering power of acid can prevent precipitation of solid compounds, particularly calcium carbonate $\left(\mathrm{CaCO}_{3}\right)$.

- Citric acid prevented iron scale formation in southwest Florida when continuously injected at $25 \mathrm{ppm}$.

- Neutralize $80 \%$ of the bases (carbonates) in the water to eliminate carbonate precipitation. (See Appendix 2 for a method to determine how much acid to inject for $80 \%$ neutralization.)

- Typical acids that can be injected to neutralize carbonates:

- Sulfuric acid

- Muriatic (hydrochloric) acid

- N-pHuric $®$ or similar compounds (see below)

- Phosphoric acid

- Do not use phosphoric acid if there is more than $50 \mathrm{ppm} \mathrm{Ca}$ in the irrigation water because calcium phosphate will likely precipitate.

- Calcium phosphate is nearly insoluble and does not readily dissolve.

- If phosphoric acid is used at a much higher concentration for line purging (see section 6), calcium phosphate will probably not precipitate.

- $\mathrm{N}$-pHuric ${ }^{\circledR}$ is a mixture of urea and sulfuric acid. It combines the benefits of adding urea nitrogen to crops with acidification while eliminating the undesirable characteristics of using sulfuric acid alone.

- $\mathrm{N}$-pHuric ${ }^{\circledR}$ is widely used in the western USA to prevent drip irrigation emitter clogging.

- Long-term acidic nitrogen fertilizers must be used with caution because:

- nitrogen should not be applied to some crops near harvest, and

- the soil pH may become too acidic with repeated applications of acidbased fertilizer.

- Use Table 4 to estimate the amount of $\mathrm{N}$-pHuric ${ }^{\circledR}$ needed to neutralize excess carbonate. 
Table 4. Quantities of $\mathrm{N}$-pHuric ${ }^{\circledR}$ required to neutralize $90 \%$ of the carbonates in 1000 gal of irrigation water (Unocal, 1993).

\begin{tabular}{|c|c|c|c|}
\hline Carbonates in water & N-pHuric ${ }^{\circledR}$ 28/27 & N-pHuric ${ }^{\circledR} 15 / 49$ & N-pHuric ${ }^{\otimes} 10 / 55$ \\
\hline ppm & oz & oz & oz \\
\hline 50 & 12 & 6 & 6 \\
\hline 100 & 24 & 13 & 11 \\
\hline 200 & 49 & 25 & 22 \\
\hline 300 & 73 & 38 & 33 \\
\hline 400 & 97 & 50 & 44 \\
\hline
\end{tabular}

- CAUTION: Always add acid to water; do not add water to acid. Adding water to acid can cause a violent reaction, and may cause the acid to splash on the person pouring the water. Individuals working with acids should wear protective clothing and eyewear. Also, be sure that adequate safety devices are provided, including a shower and eyewash.

\subsection{Synthetic scale inhibitors}

The most common alternative chemicals to chlorine and acids are scale inhibitors, which lessen scale formation by preventing precipitation reactions from occurring long enough for problem ions to clear the irrigation system. Inhibitors are usually synthetic polymer or polyphosphate mixtures. They are often combined with surfactants and penetrants to help break apart biological and crystalline solids attached to tubing walls and emitters. Water conditioners do not kill bacteria, but they alter the chemical environment so conditions for deposition or attachment are less favorable.

\subsubsection{General information}

- Scale inhibitors have been used for many years in municipal water treatment and cooling tower applications.

- Some of these compounds can remove scale, while others prevent its formation by sequestering cations, particularly iron. (Sequestration keeps metal ions in suspension without removing them from the water.)

- Some industrial compounds are sold to prevent scaling and sequester iron in microirrigation systems.

- Inhibitors are safe and easy to handle (as opposed to acid) and are often registered for drinking water applications.

- Directly adopting industrial inhibitors for microirrigation may not be successful because the water chemistry may differ significantly from an industrial system.

- Scale inhibitors can be costly because they are usually proprietary materials. 
o They are injected into irrigation systems at rates normally less than 10 ppm to keep their use affordable.

- A water analysis can help determine the most favorable combination of chemicals in a particular mixture. Some water conditioner manufacturers will not sell a product to a customer until water sample test results are known so a scaling inhibitor can be custom blended for the particular water source.

- Initial applications of scale inhibiting chemicals to poorly maintained microirrigation systems might require higher rates than normally used for routine maintenance. The increased rate may be required for several applications until system cleanliness has improved to the point that only maintenance rates are required.

- There is uncertainty about inhibitor selection and injected concentration required for various water source and irrigation system conditions.

- Based on limited experience, the best anti-plugging formulations may be a mixture of several chemicals, each with a different function.

- A satisfactory broad-spectrum formulation would suppress slimy bacterial growth and precipitation of iron, manganese, calcium, and magnesium.

- No general recommendation for scale inhibitor use is provided in this guide because of the wide variety of commercial products available and the wide variation in irrigation water source characteristics.

- Consult the manufacturers of scale-inhibiting chemicals for recommendations on the product type that is best for your situation and the concentration at which to inject it.

- If you decide to try a scale-inhibiting chemical, evaluate its performance using the guidelines given in section 5.4 .

\subsubsection{Polyphosphates}

- The most common synthetic scale inhibitors are polyphosphates:

- Polyphosphates are mixtures of various length chain molecules that have orthophosphate $\left(\mathrm{PO}_{4}{ }^{3-}\right)$ groups linked together.

o The average number of $\mathrm{P}$ atoms chained together ranges from 4 to 18 .

- There are major differences between polyphosphate compounds. Comparisons of one chemical with another are complicated and depend on water chemistry.

- Polyphosphates vary in their ability to trap and hold metal ions in solution. The effectiveness of a polyphosphate is determined by: 
o The concentration of both the metal ion and the polyphosphate in solution.

o The relative stability of the metal ion-polyphosphate combination. For example, one polyphosphate might bind metals in the order $\mathrm{Ca}>\mathrm{Mg}>$ $\mathrm{Fe}$ (strongest first), whereas another might bind in the order $\mathrm{Fe}>\mathrm{Ca}>$ $\mathrm{Mg}$.

- Typically, polyphosphates cannot sequester more than 1 to $2 \mathrm{ppm} \mathrm{Fe}$ in irrigation water; the dosage required is 2 to 5 times the Fe concentration.

- Polyphosphates usually lose their potency with storage times longer than about 4 weeks.

\subsubsection{Phosphonates and polyelectrolytes}

- Phosphonates and polyelectrolytes have also been used in municipal water industries as scale inhibitors. They differ structurally from polyphosphates.

- A polymaleic anhydride anionic terpolymer is currently sold to sequester iron and manganese.

- Iron and manganese ions attach to this polymer and pass through the irrigation system rather than oxidizing and precipitating in the lines and emitters.

- Manufacturers claim these compounds provide de-scaling of certain precipitates, including calcium phosphates and calcium carbonates.

\subsection{Evaluating water conditioning treatments}

Determine if a water conditioning treatment (injection of chlorine, acid, or a synthetic scale inhibitor) is working by monitoring the system or by installing scale-monitoring devices.

\subsubsection{Monitor the system to detect plugging}

- Keep track of system pressure with time:

- A gradual pressure increase with time at constant lift and engine speed (rpm) may indicate that emitters are slowly plugging.

- Conversely, a pressure decrease observed after injection of a water conditioner would suggest that the chemical treatment is working.

- Alternatively, keep track of system flow with time:

o Reduced flow at the same engine speed (rpm) and pressure would indicate gradual plugging.

- Increased flow after chemical treatment would indicate a reduction in plugging. 


\subsubsection{Use scale-monitoring devices to evaluate cleaning}

- A scale-monitoring device is a clean, non-scaled surface like a glass slide (Fig. 3) or short section of new tubing (Fig. 4) that is spliced into an irrigation lateral line.

- Install several devices across the irrigation system network, from laterals close to the pump to those at the far end of the system.

- Irrigate with the system as normal, and periodically check the devices for new scale deposition.

- When trying a new water treatment chemical, leave untreated at least one irrigation zone that draws from the same water source as the treated zones, and install scale monitoring devices in each.

- After a 4 to 6 week trial period of irrigation in treated and untreated zones, examine the scale-monitoring devices to see if less scale was deposited in the zone where the water treatment chemical was used.

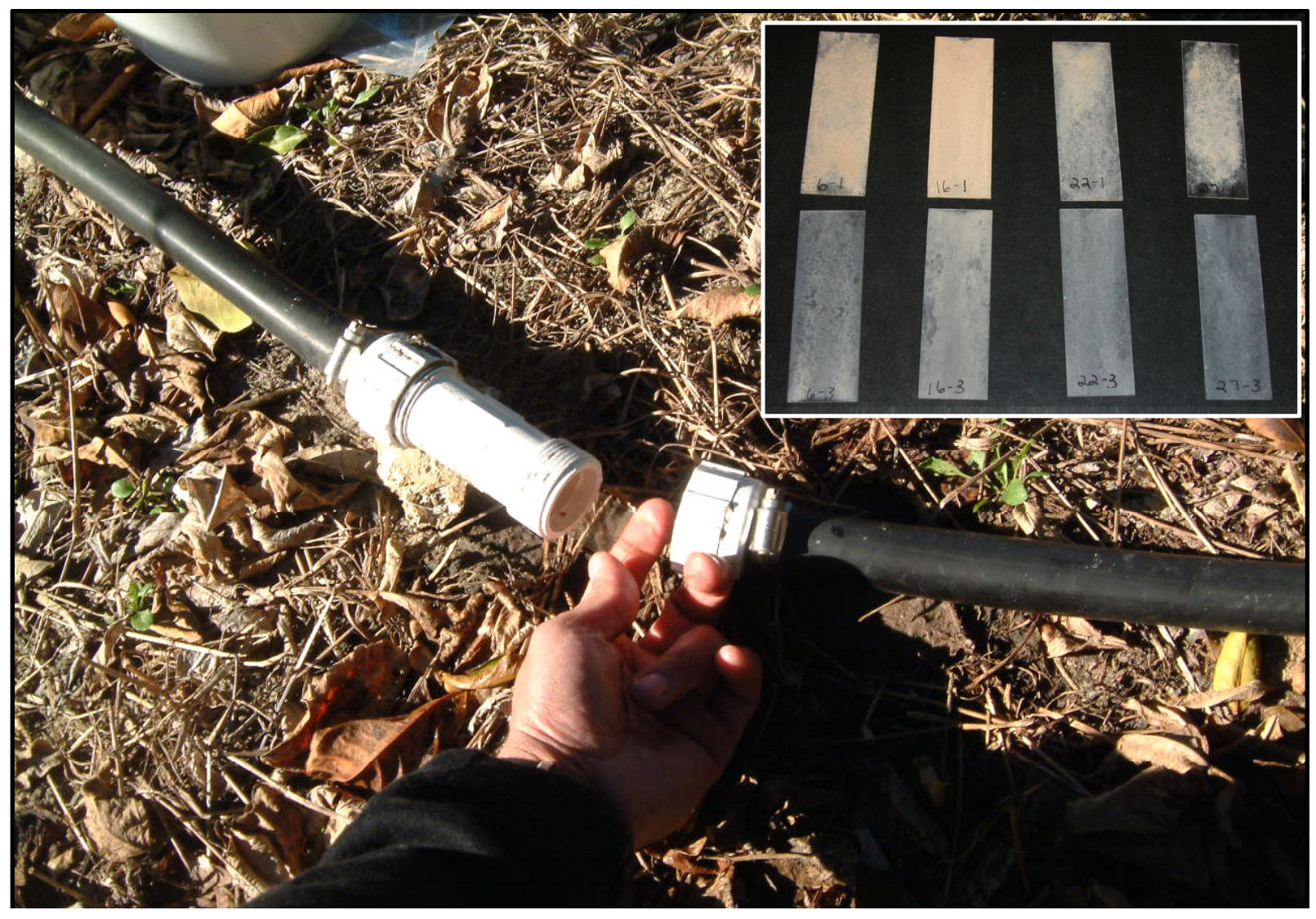

Fig. 3. A $3 / 4$-inch PVC coupling found in plumbing-supply stores can serve as an in-line glass slide holder. Observing the amount, type, and rate of scale deposition occurring on a clean slide (inset) can help determine the scaling potential of the irrigation water and the effect of injected scale-inhibiting chemicals. 


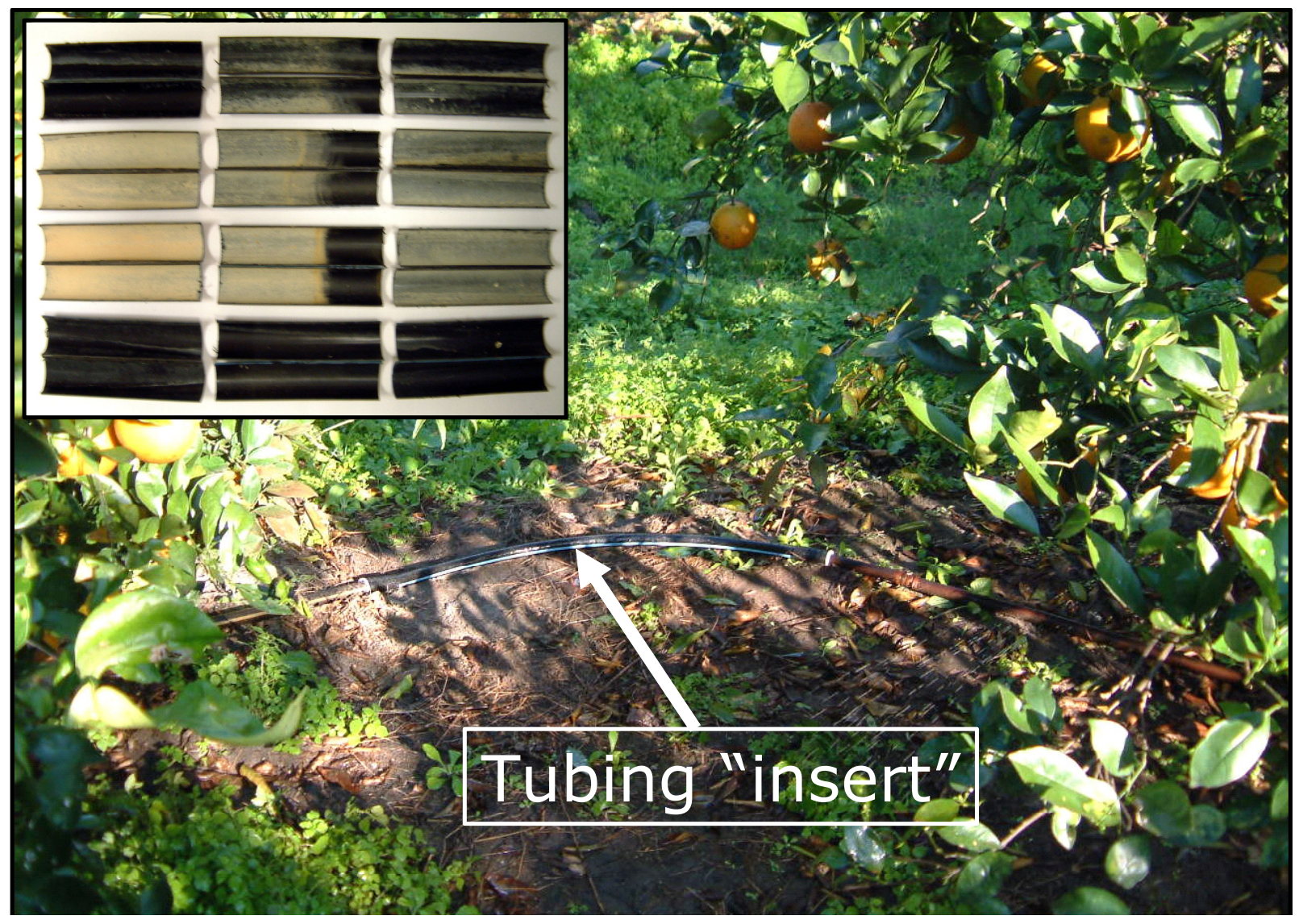

Fig. 4. A short section of new plastic tubing "inserted" into an irrigation lateral can serve as a scaling indicator. After sufficient water has passed through the line, the insert can be removed and cut open to observe newly-deposited scale (inset). The amount, type, and rate of scale deposition occurring on the tubing wall can help determine the scaling potential of the irrigation water and the effect of injected scale-inhibiting chemicals. The effect of an injected purge chemical can be evaluated by installing a section of scaled tubing prior to treatment and observing the inside walls following system flushing.

\section{REMEDIAL MAINTENANCE FOR MICROIRRIGATION SYSTEMS AFFECTED BY} SCALING OR PLUGGING

- Remedial maintenance involves "specialized" procedures that attempt to solve a microirrigation encrustation or emitter plugging problem.

- Preventing emitter plugging is usually more cost-effective than attempting to reclaim a system by chemical treatment. 


\subsection{Emitter maintenance and reclamation}

- When an irrigation system becomes severely plugged, replace the emitters with new ones or reclaim the old ones by chemically cleaning them.

- Before non-plugged emitters are reinstalled, re-analyze the irrigation water to identify the plugging source, and try to identify the material plugging the emitters.

- If the plugged material is calcium carbonate, the chance of reclamation without removing emitters from the field is good.

- If the primary cation is iron, removal and cleaning or replacement with new emitters is likely the only solution.

- Iron compounds found in plugged emitters are very difficult to unplug in the field.

- Iron-fouled emitters can be cleaned by soaking in a strong ( 0.5 to $1.0 \%)$ citric acid solution for 24 to 48 hours.

- Reclaiming plugged emitters by chemical treatment is not always successful because most of the injected chemical flows through the open emitters and not through the plugged ones.

- Consider chemical reclamation only as a last resort.

- Direct your major effort towards effective system maintenance.

- Do not clean plugged emitters by scraping or reaming with a small wire. Doing so may distort the emitter orifice and can introduce another source of non-uniformity in irrigation water application.

\subsection{Purging with acid}

- Calcium scale, and to a much lesser extent iron scale, can be purged with acid.

- For system purging, lower the $\mathrm{pH}$ of the water in the irrigation system to 2.0 or less to achieve maximum effectiveness of the acidification.

- Determine the amount of acid required to decrease the $\mathrm{pH}$ to 2.0 or less by titrating a sample of the irrigation water. A titration curve (Fig. 5) is unique for each water source and type of acid.

- Since water quality can change with time, re-titrate every few months. Use at least 1 gallon of irrigation water, an eyedropper, and a calibrated portable $\mathrm{pH}$ meter.

- Stir the irrigation water to ensure complete mixing of the acid before the $\mathrm{pH}$ is measured. 


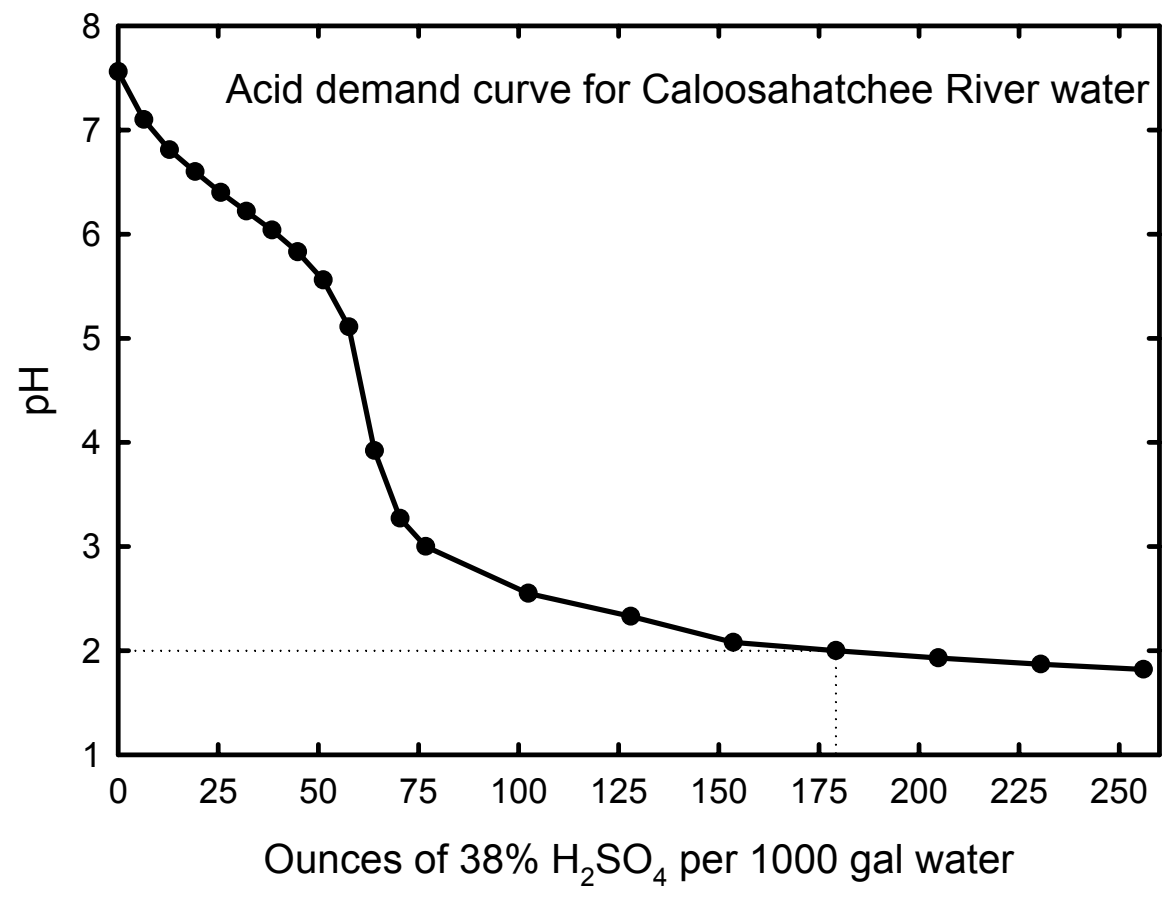

Fig. 5. Typical acid-irrigation water titration curve for south Florida surface water.

- Caution: Low pH water can damage irrigation system hardware:

- Corrosion accelerates rapidly as $\mathrm{pH}$ decreases below 5.5 .

- Injecting acid requires special filters and injection pump gaskets. Check with the manufacturer of the equipment before acid treatment to ensure compatibility.

- Design chemical injection ports to protrude into the center of the pipeline to ensure adequate mixing of acid with water.

- Typical acids that may be injected into irrigation water to purge a microirrigation system:

- Sulfuric acid - A $1 \%$ solution of sulfuric acid using $38 \% \mathrm{H}_{2} \mathrm{SO}_{4}$ as the base material removed iron scale from interior tubing walls in south Florida tests. However, removal did not necessarily mean dissolution. Sulfuric acid is effective at loosening scale without dissolving it, so line flushing following acid treatment is imperative.

- Citric acid - A 1\% citric acid solution removed iron scale from interior tubing walls in south Florida tests. In this case, the removal was due to scale dissolution (Fig. 6). 


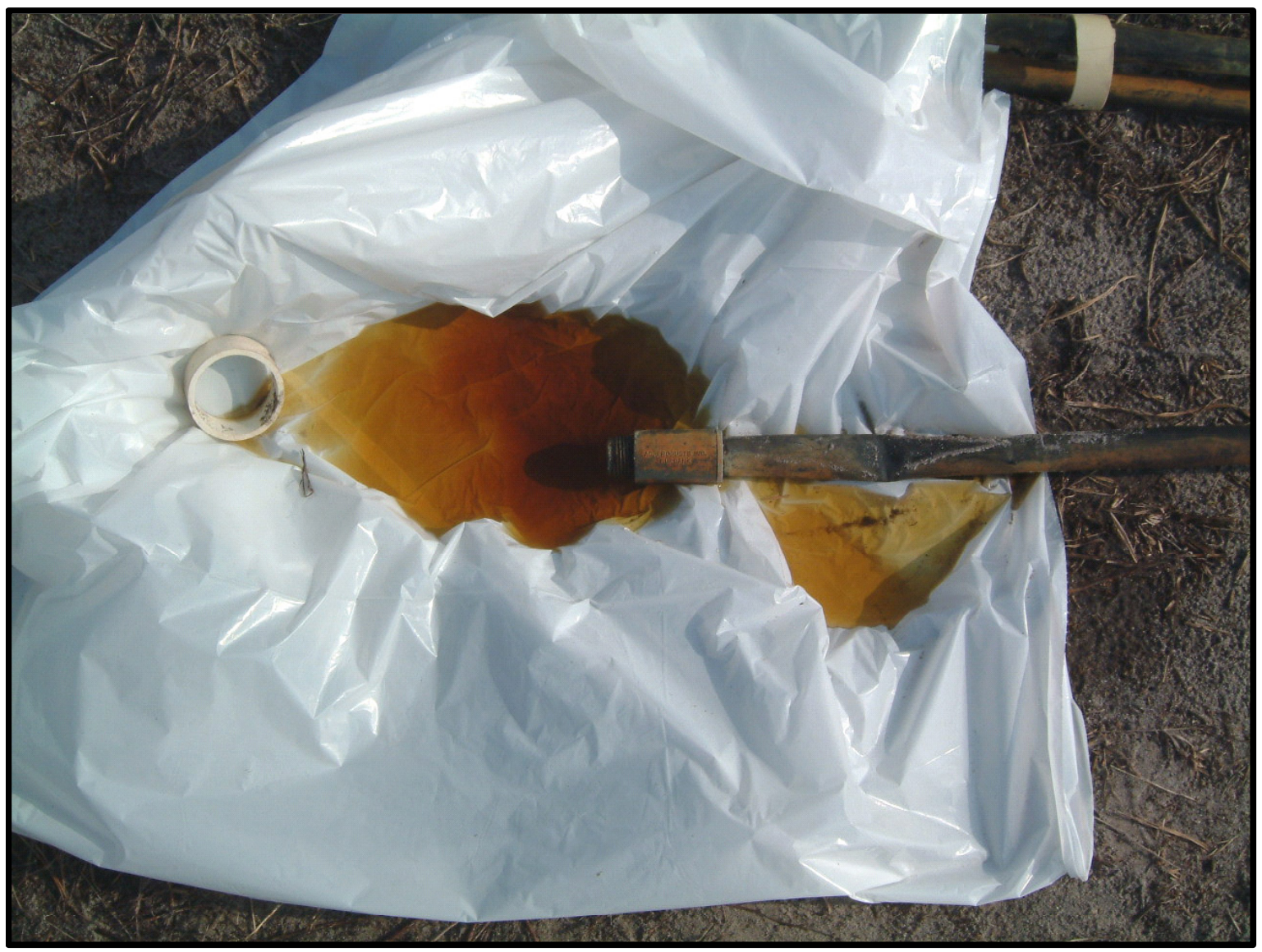

Fig. 6. The reddish-brown color of the flush water from an iron-scaled microirrigation system purged with $1 \%$ citric acid suggests that the acid dissolved the scale.

- Hydrochloric acid (sold commercially as muratic acid) can effectively remove mineral scale. Hydrochloric acid can be purchased with an inhibitor that minimizes its corrosive effect on metal parts.

- Sulfamic acid is a dry granular material that makes a strong acid when mixed with water. Although it is more expensive than hydrochloric acid and is less aggressive, sulfamic acid offers a number of advantages. In its dry form, it is relatively safe to handle. Sulfamic acid is particularly useful in treating calcium scale but is less effective on iron.

- Hydroxyacetic (glycolic) acid has been reported to be effective in treating iron scale in wells. Its effectiveness in reclaiming microirrigation system is not known.

- Use this general injection procedure:

- Inject acid just long enough for the acid-water mixture to fill the entire interior volume of the irrigation system mainlines, sub-mains, manifolds, and lateral tubing. 
- Allow the acid-water mixture to stand inside the system for at least 24 hours.

- Rinse the irrigation system using flush-out valves or by opening lateral tubing ends following acid injection. If the system is not flushed, emitter plugging could be made worse than before if small particles detached by the acid get caught in emitters.

$\circ \quad$ Evaluate purge effectiveness using the guidelines given in section 6.4.

- Acids require special filters and injection pump gaskets. Check with the manufacturer of the equipment before acid treatment to ensure compatibility.

- CAUTION: Always add acid to water; do not add water to acid. Adding water to acid can cause a violent reaction, and may cause the acid to splash on the person pouring the water. Individuals working with acids should wear protective clothing and eyewear. Also, be sure that adequate safety devices are provided, including a shower and eyewash.

\subsection{Other purge chemicals}

Commercial products designed to purge scale from microirrigation systems are now under development. As with water conditioners (scale-preventers), commercial purging products are proprietary mixtures of several chemicals. In south Florida tests, a $1 \%$ solution of one such experimental product removed 40 to $70 \%$ of iron-based scale from interior microirrigation tubing walls.

No general recommendation for commercial product use is provided in this guide because the wide variety of scaling and plugging problems found in Florida requires customized diagnosis and recommendation. If a commercial product is chosen for purging, always follow the manufacturer's recommendations for use as listed on the product label.

\subsection{Evaluating system purge treatments}

Determine if a purge treatment (injection of acid or a commercial purging product) has worked by installing monitoring devices (tubing inserts) prior to chemical injection, or by evaluating the water application uniformity of the microirrigation system.

\subsubsection{Evaluation using tubing inserts}

- Make tubing inserts by cutting short (2 to $3 \mathrm{ft}$ ) sections of used, scaled tubing from the system to be purged (Fig. 4).

- Before splicing the tubing inserts into lateral irrigation lines across the system network, cut a small section from the insert, slice it open lengthwise, and observe the scale inside.

- After installing the inserts, inject the purge chemical to clean the system. 
- After allowing time for the purge chemical work, flush it from the system.

- Re-examine the tubing inserts: cut out another small section, slice it open, and again observe the interior walls.

- Compare the "before" and "after" tubing insert sections to determine the effect of the purge treatment.

\subsubsection{Water application uniformity evaluation}

- Measure the water application uniformity of the irrigation system before a purge treatment:

- Measure it yourself using the procedure given by Smajstrla et al. (1990).

- Have the MIL or a trained professional measure it.

- After the purge treatment, re-evaluate the application uniformity to determine the effect of the purge treatment.

\section{ADDITIONAL INFORMATION ABOUT IRON, MANGANESE, AND SULFIDE}

\subsection{Iron and manganese}

Emitter plugging from iron precipitates and iron-reducing bacteria is especially difficult to control. In some geographic areas, iron causes very serious scale formation and emitter plugging problems (Fig 7.).

- Dissolved iron in irrigation water is usually caused by microbial activity.

- Iron and manganese concentrations as low as $0.2 \mathrm{ppm}$ can cause a bacterial growth problem.

- Iron bacterial growth appears reddish, while manganese bacterial growth is blacker in color. These bacteria oxidize iron or manganese in the irrigation water.

- Iron precipitation and rapid bacterial growth create enough material to plug a microirrigation system in a few weeks.

- Iron bacteria are notoriously difficult to kill, partly because they may live in the irrigation well. Periodic acid or chlorine treatments of the well are sometimes effective.

- It is not clear if iron bacteria exist in groundwater before well construction and multiply as water is pumped, or if they get into the aquifer from the soil during well construction.

- Iron oxide can form without bacteria after an irrigation system has shut down. Contact between air and water left in the line causes iron to precipitate. 


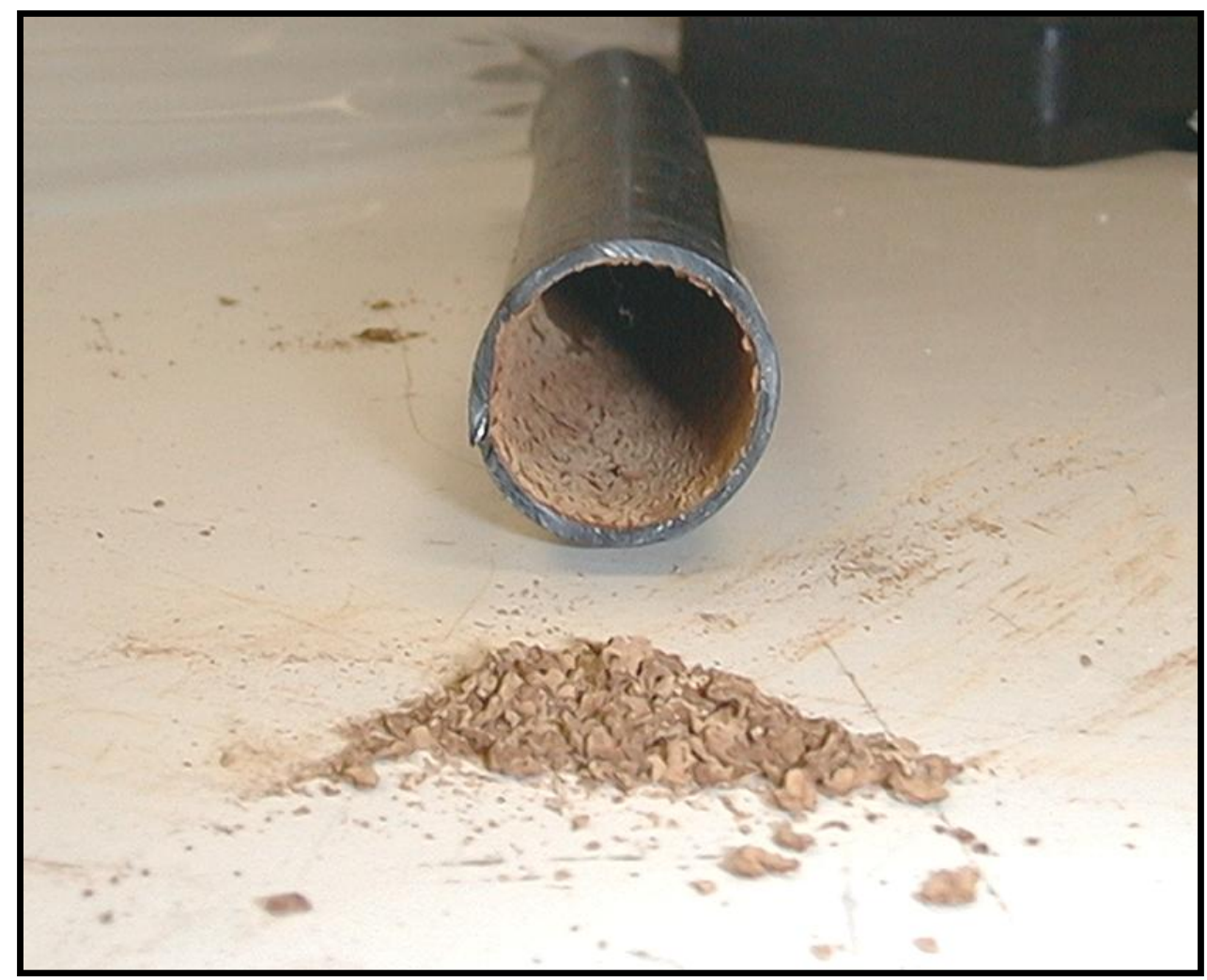

Fig. 7. Severe scaling caused by iron precipitation.

- Polyphosphates and polymaleic acid can effectively sequester iron and manganese so they remain suspended and move through the irrigation system.

- If the iron concentration is less than $3.0 \mathrm{ppm}$, water conditioning can be an effective, economical treatment.

- At higher iron concentrations, water conditioning will be costly and may be ineffective.

- Since chlorine is an oxidizer, it can precipitate iron and manganese, removing them from the irrigation water.

- Injecting chlorine gas to precipitate iron followed by filtering through fine media or discs has worked to remove iron in Florida (Bar, 1995). It is important to thoroughly mix the chlorine and water.

- Chlorine will also kill bacteria that oxidize iron and manganese, eliminating growth.

- Iron can be removed from well water by pumping it into a reservoir and aerating (oxidizing) it.

- Iron (and manganese) precipitate in the reservoir before the water is pumped for irrigation. 
- Chlorination is still required since the reservoir water takes on characteristics of surface water.

\subsection{Sulfides}

- Dissolved iron and manganese in the presence of sulfides can form a black, insoluble precipitate. Iron greater than $0.6 \mathrm{ppm}$ combined with sulfide greater than $2.0 \mathrm{ppm}$ in the water creates iron sulfide sludge.

- Sulfide problems are associated with well water, and the well casing can become rapidly clogged.

- Wells that draw water from two formations, one high in sulfides and the other high in iron, are candidates to form iron sulfide sludge. Combine aeration, acidification, and chlorination to treat this problem.

\section{SUMMARY}

- Preventive maintenance enables a microirrigation system to operate at peak efficiency and will save water and fertilizer.

- Routinely maintain pumps, power units, filters, valves, pressure gauges, flow meters, and field pipe/tubing/emitters.

- Flushing the irrigation system is critical to prevent emitter plugging.

- A plugged or scaled irrigation system requires remedial maintenance including cleaning or replacing emitters and line purging.

- Water treatment to reduce emitter plugging potential may include chlorination, acidification, and/or injection of scale inhibitors and sequestering agents.

- The effectiveness of water conditioning or purge chemicals should be evaluated with scale-monitoring devices or water distribution uniformity checks.

\section{REFERENCES AND FURTHER READING}

- Bar, llan. 1995. Iron control system for drip irrigation. In F. R. Lamm (ed.). Microirrigation for a changing world: Conserving resources/protecting the environment. Proc. of the $5^{\text {th }}$ International Microirrigation Congress, Orlando, FL. ASAE publication 4-95, ASAE, St. Joseph, MI.

- Boman, Brian. 2002. Prevention of emitter clogging. Chapter 36 In B. J. Boman (ed.). Water and Florida citrus: use, regulation, irrigation, systems, and management. Univ. of Florida-IFAS pub. SP-261.

- Burt, C., K. O'Connor, and T. Ruehr. 1998. Fertigation. Irrigation Training and Research Center, California Polytechnic State Univ., San Luis Obispo, CA. 
- Pitts, D. J., D. Z. Haman, and A. G. Smajstrla. 1990. Causes and prevention of emitter plugging in microirrigation systems. Bulletin 258, Fla. Coop. Ext. Serv., IFAS, Univ. of Florida (EDIS document no. AE032).

- Smajstrla, A. G., B. J. Boman, D. Z. Haman, D. J. Pitts, and F. S. Zazueta. 1990. Field evaluation of microirrigation water application uniformity. Bulletin 265, Fla. Coop. Ext. Serv., IFAS, Univ. of Florida (EDIS document no. AE094).

- Unocal Corp. 1993. N-pHuric ${ }^{\circledR}$ reference manual. Unocal Corp., Sacramento, CA. 


\section{APPENDIX 1}

Table A-1-1. General summary of microirrigation problems and possible solutions (Burt et al., 1998).

\begin{tabular}{|c|c|}
\hline Problem & Possible solution \\
\hline Small slimy bacteria & $\begin{array}{l}\text { 1. Continuously apply chlorine at low dosage. Free chlorine } \\
\text { at the far end of the system should measure } 1 \mathrm{ppm} \text {. } \\
\text { 2. Superchlorinate to } 200 \text { to } 500 \text { ppm free chlorine at the far } \\
\text { end of the system: Thoroughly flush system, inject } \\
\text { chlorine, allow to sit overnight, flush system the next day. }\end{array}$ \\
\hline $\begin{array}{l}\text { Iron and manganese } \\
\text { bacteria }\end{array}$ & $\begin{array}{l}\text { 1. If the bacteria inhabit the well, injecting acid or chorine } \\
\text { directly into it may minimize the problem. Check for } \\
\text { legality of this procedure in the local area. } \\
\text { 2. Pump well water into a reservoir and aerate it before } \\
\text { pumping it to the irrigation system. The oxidation will } \\
\text { cause precipitation of iron and manganese. } \\
\text { 3. Inject a long chain linear polyphosphate or polymaleic } \\
\text { acid into the irrigation water to sequester iron and } \\
\text { manganese, keeping them suspended while they move } \\
\text { through the irrigation system. } \\
\text { 4. Inject chlorine gas ( } 1.4 \text { parts chlorine for each } 1.0 \text { part } \\
\text { iron in the water) prior to a fine media or disc filter to } \\
\text { precipitate the iron from the water and trap it in the filter. } \\
\text { This technique will not work for manganese. }\end{array}$ \\
\hline $\begin{array}{l}\text { Calcium and magnesium } \\
\text { carbonate precipitation }\end{array}$ & $\begin{array}{l}\text { 1. Neutralize the carbonates by injecting phosphoric or } \\
\text { sulfuric acid into the irrigation water such that the pH } \\
\text { decreases below } 6.5 \text {. } \\
\text { 2. Inject a very long chain linear polyphosphate into the } \\
\text { irrigation water at a rate of } 1 \text { to } 2 \text { ppm to sequester } \\
\text { calcium and magnesium, keeping them suspended while } \\
\text { they move through the irrigation system. }\end{array}$ \\
\hline
\end{tabular}




\section{APPENDIX 2}

\section{Acidifying irrigation water to prevent calcium carbonate scale formation..... When and how to do it}

- If necessary, Florida irrigation water can be acidified to neutralize excess carbonate $\left(\mathrm{CO}_{3}{ }^{2-}\right)$ and bicarbonate $\left(\mathrm{HCO}_{3}{ }^{-}\right)$that occurs naturally in waters originating from limestone aquifers.

- Excess carbonate is most likely to occur wherever the irrigation water source is a limestone aquifer, which includes most of Florida.

- How to determine if a potential problem exists:

1. The best way to determine if irrigation water contains an excessive carbonate concentration is to have the water tested for liming potential by titrating it with an acid.

2. If titration is not available, the next best way is to estimate the carbonate concentration from the calcium and magnesium concentrations.

- This estimation assumes that most of the $\mathrm{Ca}$ and $\mathrm{Mg}$ in a water sample is a result of dissolved $\mathrm{Ca}$ and $\mathrm{Mg}$ carbonates.

- To estimate total carbonates (bases) from a $\mathrm{Ca} / \mathrm{Mg}$ water test, use this formula:

$\mathrm{meq} / \mathrm{L}$ of bases $=(\mathrm{ppm} \mathrm{Ca} \times 0.05)+(\mathrm{ppm} \mathrm{Mg} \times 0.083)$.

- Determining how much acid to apply to irrigation water is a several step process. The amount depends on the bicarbonate concentration in the water and the strength of the acid used. Properties of common acids are shown in Table A-2-1.

- Use the following steps to calculate the amount of acid to apply:

1. Have your irrigation water sample analyzed for total carbonates.

2. From Table A-2-1, determine the appropriate rate calculation factor for the acid to be used.

3. Multiply the factor by the milliequivalents of base per liter (meq/L) that the water contains.

4. The result is the $\mathrm{mL}$ of acid that should be applied per 100 gallons of irrigation water. To convert from $\mathrm{mL}$ to fluid ounces, divide $\mathrm{mL}$ by 29.6. 


\section{Example calculation}

1. An irrigation water sample contains $4 \mathrm{meq} / \mathrm{L}$ of base.

2. The acid to be used is $93 \%$ sulfuric.

3. How much acid needs to be injected for each 100 gallons of irrigation water applied?

4. The factor for $93 \%$ sulfuric acid is 8.7 .

5. $4 \mathrm{meq} / \mathrm{L} \times 8.7=34.8$.

6. Therefore, need to inject $34.8 \mathrm{~mL}(1.2 \mathrm{oz})$ acid per 100 gallons of irrigation water.

- This acid addition will neutralize $80 \%$ of the bases in the water. It is not necessary to neutralize $100 \%$ in order to make the bicarbonate problem insignificant. Not trying to neutralize all of the bicarbonates allows some room for error. The risk of over acidification is not worth it.

- Acids are highly toxic and corrosive chemicals, and should be handled with great care. Precautions when using acids include:

- Use goggles and protective clothing when handling.

- When mixing acids with water, always add the acid to the water, never vice-versa, in a well-ventilated area.

- Dilute concentrated acid with water in a non-metal mixing tank prior to injecting into the irrigation system.

- Avoid over-application, which can severely damage plants.

\section{Summary}

1. Have your irrigation water tested.

2. Select an acid of known strength.

3. Determine how much of your acid is needed to neutralize $80 \%$ of the bases in your water.

4. Inject the calculated rate of acid into your irrigation water.

5. Measure the $\mathrm{pH}$ of the water as it comes out of the irrigation line.

6. If the $\mathrm{pH}$ is not between 4.5 and 5.0, increase or decrease the amount of acid.

7. Re-test the water source and irrigated soil about once a year to check for any changes. 
Table A-2-1. Properties of common acids.

\begin{tabular}{|ccc|}
\hline Acid & Strength & Rate calculation factor \\
\hline Sulfuric & $93 \%$ & 8.7 \\
$\begin{array}{c}\text { Muriatic } \\
\text { (Hydrochloric) }\end{array}$ & $32 \%$ & 29.6 \\
Phosphoric & $85 \%$ & 6.8 \\
\hline
\end{tabular}

